\title{
Esthetic Index for Anterior Maxillary Implant-Supported Restorations
}

\author{
Gintaras Juodzbalys* and Hom-Lay Wang ${ }^{\dagger}$
}

Background: The aim of this study is to develop and validate a complex esthetic index (CEI) designed for rating the esthetics of anterior maxillary implant-supported restorations with respect to the surrounding soft and hard tissues.

Methods: Fifty patients ( 31 males and 19 females; age: 18 to 50 years; mean age \pm SD: $32.4 \pm 9.1$ years) previously treated with dental implants were evaluated regarding the esthetic results of their restorations using the proposed CEI. Two calibrated oral surgeons did the evaluation and recording. The evaluation was carried out twice by each of the examiners 2 weeks apart. The weighted Cohen's $\mathrm{\kappa}$ was used to calculate the intra- and interobserver agreement.

Results: An analysis of CEI for 50 anterior maxillary implant-supported restorations showed good intra- and interobserver agreement for the soft tissue index (S) and implantsupported restoration index (R). Only the interobserver agreement for the overall $\mathrm{R}$ was rated as moderate $(0.54$ and $0.52)$. The single-parameter analysis showed that the lowest (moderate) intra- and interobserver agreement was with the subjective parameters of S (soft tissue color and texture variations) and $\mathrm{R}$ (crown surface roughness and ridges and color and translucency). An adequate CEI of S100, P100, and R100 was scored by both examiners in $10 \%$ and $12 \%$ of cases for evaluations I and II, respectively.

Conclusions: This study presents evidence that this newly developed CEI, which incorporates the implant restoration and adjacent soft and hard tissue parameters, is a reproducible tool for scoring anterior implant esthetic predictably. However, prospective clinical trials involving examiners with different training backgrounds are needed to further validate the long-term stability of this index. J Periodontol 2010;81:34-42.

\section{KEY WORDS}

Dental implants, single-tooth; dental prosthesis, implant-supported.

\footnotetext{
* Department of Oral and Maxillofacial Surgery, Kaunas University of Medicine, Kaunas, Lithuania.

$\dagger$ Department of Periodontics and Oral Medicine, University of Michigan, Ann Arbor, MI.
}

$\mathrm{T}$ he use of implants has evolved into an accepted, predictable treatment for replacing missing teeth. Implant rehabilitation is no longer just a vehicle to restore lost masticatory and phonetic function; it has become an integral part of modern implant dentistry for achieving structural and esthetically pleasing outcomes. ${ }^{1}$ Implant-supported restorations should imitate the appearance of natural teeth. ${ }^{1-4}$ Furthermore, the implant-supported restoration should be in symmetry with the adjacent dentition. ${ }^{5}$ To ensure that optimal esthetics can be achieved during implant rehabilitation, the following prerequisites are considered essential: adequate bone volume (horizontal, vertical, and, contour), optimal implant position (mesiodistal, apico-coronal, bucco-lingual, and angulation), stable and healthy periimplant soft tissues, and an esthetic soft tissue contour. ${ }^{1,6-9}$

Quantitatively evaluating esthetic results is quite new and has not been fully developed in implant dentistry. Most authors evaluated factors that encompass only a portion of our proposed complex esthetic index (CEI) for anterior maxillary implant-supported restorations. For example, Furhauser et al. $^{5}$ proposed the pink esthetic score (PES) to evaluate seven soft tissue parameters (mesial and distal papilla, alveolar process, soft-tissue texture, contour, and color, and level of the soft tissue margin) around single-tooth implant crowns. Meijer et al. ${ }^{10}$ proposed a new index for rating esthetics of implant-supported

doi: 10.1902/jop.2009.090385 
single crowns and adjacent soft tissues. The index consists of nine parameters that are based on the anatomic form, color, and surface characteristics of the crown and peri-implant soft tissues. Recently, Belser et al. ${ }^{11}$ modified the PES classification system (assessed mesial papilla, distal papilla, curvature of the facial mucosa, level of the facial mucosa, and root convexity/soft tissue color and texture at the facial aspect of the implant site) and proposed a white esthetic score that included the general tooth form, outline and volume of the clinical crown, color (which includes the assessment of the dimension's hue and value and surface texture), and translucency to assess an implantsupported restoration. To our knowledge, there is no clear and statistically proven reproducible esthetic index that considers all potential influencing factors. One of the main issues surrounding these published classifications is that factors involving hard tissue (alveolar bone) are lacking. It is well established that the soft tissue appearance is largely dependent upon the underlying bone topography. ${ }^{12}$ Hence, it is important to include a hard tissue assessment, such as horizontal bone deficiency and interproximal bone height, into any newly proposed esthetic index. Chen et al. ${ }^{6}$ showed that implants with a buccally oriented shoulder position had three times more recession than implants with a lingual shoulder position. Furthermore, more tissue recession was noted in thin tissue biotype sites than in thick tissue biotype sites. Hence, an implant-supported restoration esthetic index should have a prognostic value that includes both soft and hard tissues. The aim of this study is not only to develop but also to validate a CEI for rating the esthetics of anterior maxillary implant-supported restorations and their surrounding soft and hard tissues.

\section{MATERIALS AND METHODS}

\section{Subject Sample}

Between January and April 2009, 50 patients (31 males and 19 females; age: 18 to 50 years; mean age \pm SD: $32.4 \pm 9.1$ years) previously treated with dental implants were investigated in the Department of Maxillofacial Surgery, University of Kaunas, for implant esthetic outcomes using the proposed CEI. All implants $^{\ddagger}$ were restored with abutments $\S$ and cement-retained restorations. The locations of the dental implants are shown in Figure 1. All participants read and signed an informed consent form. The use of human subjects in this study was reviewed and approved by the Health Science Institutional Review Board of the University of Kaunas. Subjects had to fulfill the following criteria to be included in the study: 1) single dental implants placed and restored between 1 and 2 years prior to the evaluation; 2) all evaluated implants in the esthetic zone of the maxilla, including first premolars; 3 ) adjacent teeth not restored with im-

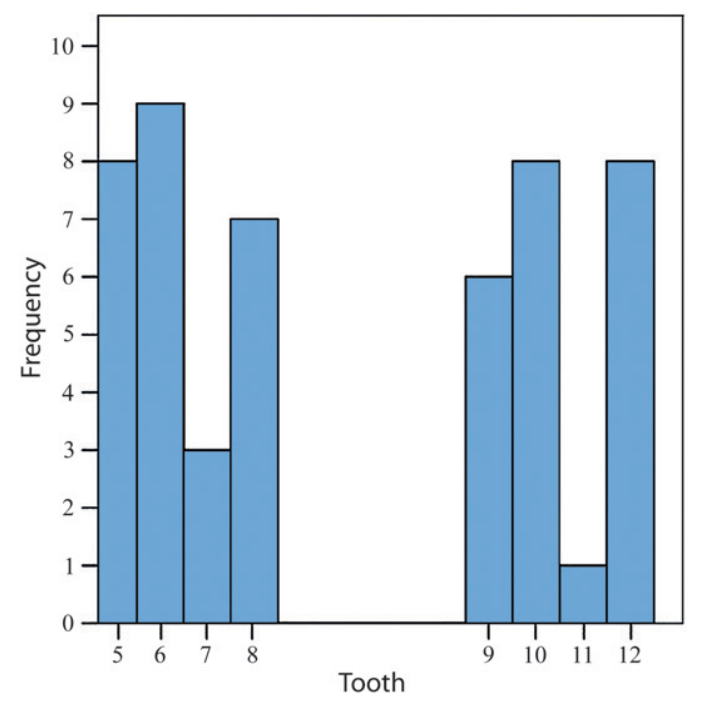

Figure I.

Distribution of anterior maxillary dental implants.

plants or prosthetic restorations; and 4) available clinical records.

\section{CEI for Anterior Maxillary Implant-Supported Restorations}

Table 1 is an overview of the proposed CEI. This esthetic index is composed of three components: the soft tissue index (S), predictive index (P), and implant-supported restoration index (R). Within each category, specific parameters were evaluated and graded as adequate (rating $20 \%$ ), compromised (rating $10 \%$ ), or deficient (rating $0 \%$ ).

Soft tissue characteristics of the $\mathrm{S}$ that were previously published ${ }^{8}$ include soft tissue contour variations, soft tissue vertical deficiency, soft tissue color and texture variations, and mesial and distal papillae appearance.

The P primary assessed the following components: mesial and distal interproximal bone height, gingival tissue biotype, apico-coronal position of the implants, and horizontal contour deficiency. For the measurement of the interproximal marginal bone level, standardized periapical radiographs were taken using a customized film holder." The long-cone paralleling technique was used to determine the mesial and distal interproximal bone height. The evaluation was performed in a linear fashion from the cemento-enamel junction (CEJ) of the adjacent teeth to the mesial and distal alveolar bone crest using standardized computerized dental-imaging software. "The implant apico-coronal position was recorded in the same way

‡ Standard Plus, Straumann, Basel, Switzerland.

$\S$ SynOcta abutments for cement-retained restorations, Straumann, Basel, Switzerland.

|| Rinn film holder, XCP Instruments, Rinn, Elgin, IL.

II KODAK OMS Imaging Software, Carestream Health, Rochester, NY. 
Table I.

\section{CEI for an Anterior Maxillary Implant-Supported Restoration: S, P, and R Assessment Ratings and Evaluation Grades}

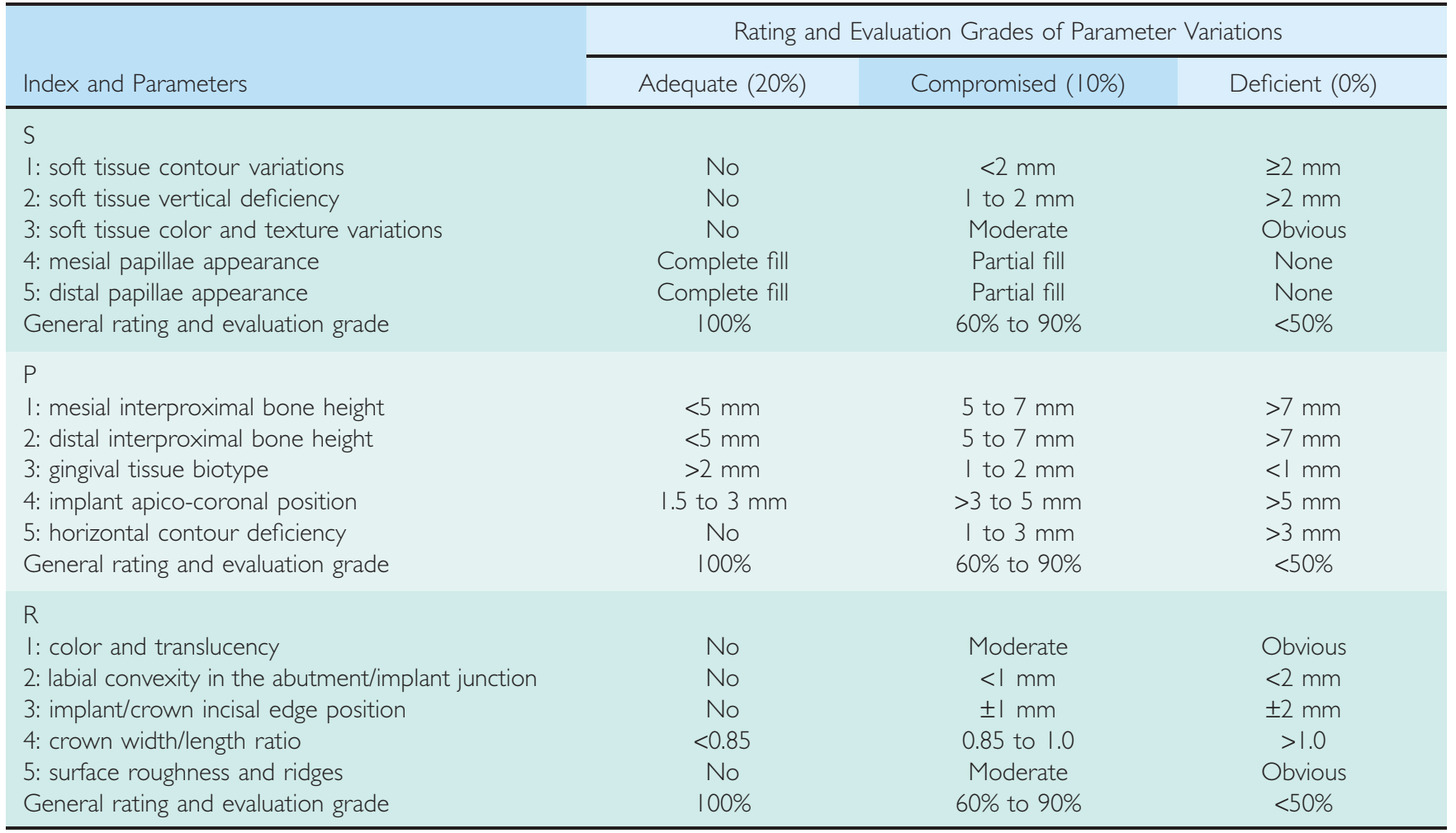

to measure the dental-implant shoulder position. The gingival tissue biotype was evaluated as previously published. ${ }^{8}$ The horizontal contour deficiency was assessed using a periodontal probe measuring from the middle part of the dental implant to an imaginary line drawn to the buccal bone flange of the adjacent teeth. Distances of 0,1 to 3 , and $>3 \mathrm{~mm}$ were defined as adequate, compromised, and deficient grades, respectively.

The R evaluated the color and translucency of the implant-supported restoration, labial convexity in the abutment/implant junction, implant/crown incisal edge position, crown width/length ratio, and surface roughness and ridges of the implant-supported restoration in relationship to adjacent and contralateral teeth. All mentioned $\mathrm{R}$ parameters, with the exception of crown width/length ratio, must be in harmony with the adjacent and contralateral teeth. The variation in parameter ratings for each grade is shown in Table 1. Crown width/length ratios of $<0.85,0.85$ to 1.0 , and $>1.0$ were defined as adequate, compromised, or deficient.

To make the CEI more informative, each component of the indices ( $S, P$, and $R$ ) is described independently. As mentioned above, each component consisted of five separate parameters defined as adequate $(20 \%)$, compromised $(10 \%)$ and deficient $(0 \%)$. Consequently, when the S, P, and R general ratings were adequate, the CEI rating was $100 \%$. When one of the indices registered between $60 \%$ and $90 \%$, this was a compromised and clinically acceptable result. When the CEI was $<50 \%$, this was a deficient and clinically unacceptable esthetic outcome. For example, when the CEI was adequate, it was expressed as S100, P100, and R100.

For the measurement of the interproximal marginal bone level, standardized periapical radiographs were obtained using a customized film holder ${ }^{\#}$ with a rigid film-object $x$-ray source coupled to a beam-aiming device to achieve a reproducible exposure geometry. The long-cone paralleling technique was used with the aim of viewing the implant threads clearly. When deviation from optimal $\mathrm{x}$-ray geometry was observed, the radiograph was retaken during the same visit. To assess the mesial and distal interproximal bone height, linear radiographic measurements were made using standardized computerized system

\# Rinn film holder, XCP Instruments, Rinn. 
dental-imaging software.** Linear measurements were defined as the mesial and distal distance from the CEJ of the adjacent teeth to the highest point of the alveolar crest. The measurements were obtained by drawing a line through the mesial and distal aspect of the CEJ and measuring the distance perpendicularly to this line at the highest alveolar crest height on adjacent teeth. The implant apico-coronal position was obtained by measuring the distance from drawing a perpendicular line through the mesial and distal aspect of the CEJ at the dental implant shoulder.

Two calibrated oral surgeons (examiners 1 [GJ] and 2 [Dr. Dalius Sakavicius, Associate Professor, Department of Oral and Maxillofacial Surgery, Kaunas University of Medicine, Lithuania]) did the evaluation and recording. All linear measurements were recorded to the nearest $1 \mathrm{~mm}$ with the use of a periodontal probe. ${ }^{\dagger \dagger}$ Triple recordings were performed, and the mean value was calculated. The evaluation was carried out twice by each of the examiners. There was a 2 -week time period between the evaluations to prevent recollection of the first evaluation.

\section{Statistical Analyses}

Statistical analyses were performed using a statistical program. ${ }^{\ddagger}$ The weighted Cohen's $\kappa$ was calculated to express the intra- and interobserver agreement. $\kappa$ represents the observed proportion of non-chance agreement. Means and standard deviations were also calculated.

\section{RESULTS}

\section{$S$ Evaluation}

The intra- and interobserver agreement and weighted Cohen's $\kappa$ for S parameters are listed in Table 2. Overall, good and very good agreements were noted. The lowest intraobserver agreement of 0.8 and 0.55 was for the soft tissue color and texture variations. Similarly, the lowest agreement of 0.74 was observed for the soft tissue color and texture variations in evaluation I and 0.43 in evaluation II.

Table 3 shows good or very good intra- and interobserver $\mathrm{S}$ agreement. Examiner 1 recorded the $\mathrm{S}$ as compromised in $29(58 \%)$ cases, adequate in 13 (26\%) cases, and deficient in eight $(16 \%)$ cases. The mean $\mathrm{S}$ was $77.4 \%$ in both periods of evaluation as evaluated by examiner 1 . A similar recording was noted by examiner 2 , who scored $28(56 \%)$ cases as compromised, $14(28 \%)$ cases as adequate, and eight $(16 \%)$ cases as deficient. The mean $S$ was $78.0 \%$ and $78.4 \%$ as evaluated by examiner 2 in evaluation periods I and II, respectively. Figure 2A shows the almost even distribution of the $S$ cumulative percentage depending on S grade, evaluation period, and examiner.

\section{$P$ Evaluation}

The intra- and interobserver agreement and weighted Cohen's $\kappa$ for the P parameters are listed in Table 2. There were good and very good agreements for all $P$ items. The intraobserver agreement was 0.91 and 0.84 for examiners 1 and 2, respectively. The lowest agreement for examiner 1 was 0.9 for mesial interproximal bone height and, for examiner 2, was 0.92 for distal interproximal bone height and horizontal contour deficiency.

For the interobserver $\mathrm{P}$ agreement, 0.79 and 0.61 were found for evaluations I and II, respectively. The lowest agreement was found for the gingival tissue biotype variations in evaluation I and 0.77 for mesial interproximal bone height in the evaluation II.

Analysis of the distribution of $\mathrm{P}$ grades revealed that examiner 1 had the same number 28 (56\%) of compromised $\mathrm{P}$ in both periods of evaluation (Table 3 ). A slight difference was noted in the other two grades. Similar observations were noted for examiner 2 in the index rating. The mean $P$ was $67.4 \%$ and $66.6 \%$ evaluated by examiner 1 and $67.6 \%$ and $67.4 \%$ recorded by examiner 2 for evaluations I and II, respectively. Figure 2B shows an almost even distribution of the $\mathrm{P}$ cumulative percentage depending on the $\mathrm{P}$ grade, evaluation period, and examiner.

\section{Implant-Supported $R$ Evaluation}

Table 2 lists the intra- and interobserver agreement and weighted Cohen's $\kappa$ for the R parameters. A very good agreement of 0.92 and 0.84 was noted for both examiners (1 and 2). Examiner 1 had the lowest agreement of 0.93 for crown width/length ratio and examiner 2 had and agreement of 0.76 for crown color and translucency recording.

A moderate interobserver agreement $(0.54$ and 0.52 ) was identified in evaluations I and II. The lowest agreement in evaluation I was for crown surface roughness and ridges (0.63) and, for evaluation II, was for color and translucency (0.49).

Examiner 1 scored 35 (70\%) and 36 (72\%) of a compromised $\mathrm{R}$ in both periods of evaluation (Table 3 ). This was almost identical for examiner 2 , who recorded $40(80 \%)$ and $34(68 \%)$ for evaluations I and II. The mean $\mathrm{R}$ was almost identical for both examiners $(82.8 \%$ to $83.6 \%)$. Figure $2 \mathrm{C}$ shows that the cumulative percentage of the $\mathrm{R}$ depending on grade, evaluation period, and examiner was distributed evenly.

\section{CEI Evaluation}

Table 3 illustrates the results of the CEI. An adequate CEI of S100, P100, and R100 was observed by both

\footnotetext{
* * KODAK OMS Imaging Software, Carestream Health.

$\dagger \dagger$ UNC-15 probe, Hu-Friedy, Chicago, IL.

牛 SPSS/PC + statistical program, version 13.0 for Windows, SPSS, Chicago, IL.
} 
Table 2.

\section{S, P, and R Parameter Evaluation: Intra- and Interobserver Agreement and Weighted Cohen's $\kappa$}

\begin{tabular}{|c|c|c|c|c|c|c|c|c|}
\hline \multirow[b]{3}{*}{ Assessment } & \multicolumn{4}{|c|}{ Intraobserver Agreement } & \multicolumn{4}{|c|}{ Interobserver Agreement } \\
\hline & \multicolumn{2}{|c|}{ Examiner I } & \multicolumn{2}{|c|}{ Examiner 2} & \multicolumn{2}{|c|}{$\begin{array}{l}\text { Examiner I Versus } \\
\text { Examiner 2: Evaluation I }\end{array}$} & \multicolumn{2}{|c|}{$\begin{array}{l}\text { Examiner I Versus } \\
\text { Examiner 2: Evaluation I }\end{array}$} \\
\hline & $\begin{array}{l}\text { Observed } \\
\text { Agreement } \\
(\%)\end{array}$ & Cohen's א & $\begin{array}{c}\text { Observed } \\
\text { Agreement } \\
\text { (\%) }\end{array}$ & Cohen's K & $\begin{array}{l}\text { Observed } \\
\text { Agreement } \\
\text { (\%) }\end{array}$ & Cohen's к & $\begin{array}{l}\text { Observed } \\
\text { Agreement } \\
(\%)\end{array}$ & Cohen's k \\
\hline \multicolumn{9}{|l|}{ S } \\
\hline $\begin{array}{l}\text { Soft tissue contour } \\
\text { variations }\end{array}$ & 100 & 1.0 & 98.0 & 0.96 & 98.0 & 0.96 & 96.0 & 0.92 \\
\hline Soft tissue vertical deficiency & 100 & 1.0 & 98.0 & 0.96 & 98.0 & 0.96 & 100 & 1.0 \\
\hline $\begin{array}{l}\text { Soft tissue color and texture } \\
\text { variations }\end{array}$ & 92.0 & 0.8 & 86.0 & 0.55 & 90.0 & 0.74 & 80.0 & 0.43 \\
\hline Mesial papillae appearance & 100 & 1.0 & 98.0 & 0.96 & 100 & 1.0 & 98.0 & 0.96 \\
\hline Distal papillae appearance & 100 & 1.0 & 100 & 1.0 & 100 & 1.0 & 100 & 1.0 \\
\hline General overall items & 92.0 & 0.9 & 88.0 & 0.86 & 86.0 & 0.83 & 78.0 & 0.73 \\
\hline \multicolumn{9}{|l|}{$\mathrm{P}$} \\
\hline $\begin{array}{l}\text { Mesial interproximal } \\
\text { bone height }\end{array}$ & 94.0 & 0.9 & 96.0 & 0.93 & 96.0 & 0.93 & 86.0 & 0.77 \\
\hline $\begin{array}{l}\text { Distal interproximal } \\
\text { bone height }\end{array}$ & 96.0 & 0.93 & 94.0 & 0.92 & 96.0 & 0.96 & 90.0 & 0.82 \\
\hline Gingival tissue biotype & 98.0 & 0.97 & 100 & 1.0 & 90.0 & 0.84 & 92.0 & 0.87 \\
\hline $\begin{array}{l}\text { Implant apico-coronal } \\
\text { position }\end{array}$ & 98.0 & 0.96 & 98.0 & 0.96 & 98.0 & 0.96 & 98.0 & 0.96 \\
\hline Horizontal contour deficiency & 100 & 1.0 & 96.0 & 0.92 & 94.0 & 0.88 & 94.0 & 0.88 \\
\hline General overall items & 92.0 & 0.91 & 86.0 & 0.84 & 82.0 & 0.79 & 66.0 & 0.61 \\
\hline \multicolumn{9}{|l|}{ R } \\
\hline Color and translucency & 98.0 & 0.94 & 92.0 & 0.76 & 78.0 & 0.65 & 80.0 & 0.49 \\
\hline $\begin{array}{l}\text { Labial convexity in the } \\
\text { abutment/implant junction }\end{array}$ & 100 & 1.0 & 98.0 & 0.96 & 92.0 & 0.85 & 90.0 & 0.81 \\
\hline $\begin{array}{l}\text { Implant/crown incisal edge } \\
\text { position }\end{array}$ & 98.0 & 0.94 & 98.0 & 0.94 & 98.0 & 0.94 & 98.0 & 0.94 \\
\hline Crown width/length ratio & 96.0 & 0.93 & 100 & 1.0 & 96.0 & 0.93 & 100 & 1.0 \\
\hline Surface roughness and ridges & 98.0 & 0.94 & 96.0 & 0.85 & 88.0 & 0.63 & 90.0 & 0.65 \\
\hline General overall items & 94.0 & 0.92 & 84.0 & 0.84 & 64.0 & 0.54 & 62.0 & 0.52 \\
\hline
\end{tabular}

examiners in $10 \%$ and $12 \%$ of cases in evaluations I and II, respectively (Fig. 3A). Further analysis revealed the importance of each $\mathrm{CEI}$ component. It was found that in situations where the CEI was $\mathrm{S} 100, \mathrm{P} 100$, and $\mathrm{R}<100 \%$, the number of cases was the same as it was using the adequate CEI (Fig. $3 B$ ). When the $\mathrm{P}$ was $<100 \%$, the number of cases with adequate $\mathrm{S}$ and $\mathrm{R}$ was reduced more than twice. When the $S$ was $<100 \%$, the number of cases with adequate $\mathrm{P}$ and $\mathrm{R}$ was significantly reduced.

\section{DISCUSSION}

Esthetic-outcome assessment has become an emerging area of focus in implant dentistry. This is particu- larly true for anterior maxillary implant-supported restorations. To sustain the esthetic appearance, it is essential to consider surrounding soft and hard tissue characteristics and how they relate to adjacent structures. Studies ${ }^{5,10,11}$ published in this field tended to focus only on a few of these factors. It is quite evident that, when esthetics are considered, authors should examine and evaluate all soft and hard tissue parameters and implant-supported restoration because all these factors are important for long-term esthetic stability. For instance, horizontal bone level and interproximal bone height are tightly correlated to the stability and appearance of the peri-implant soft tissue. ${ }^{12}$ Interestingly, Chen et al. ${ }^{6}$ showed that the thin tissue biotype had more implant soft tissue recession 

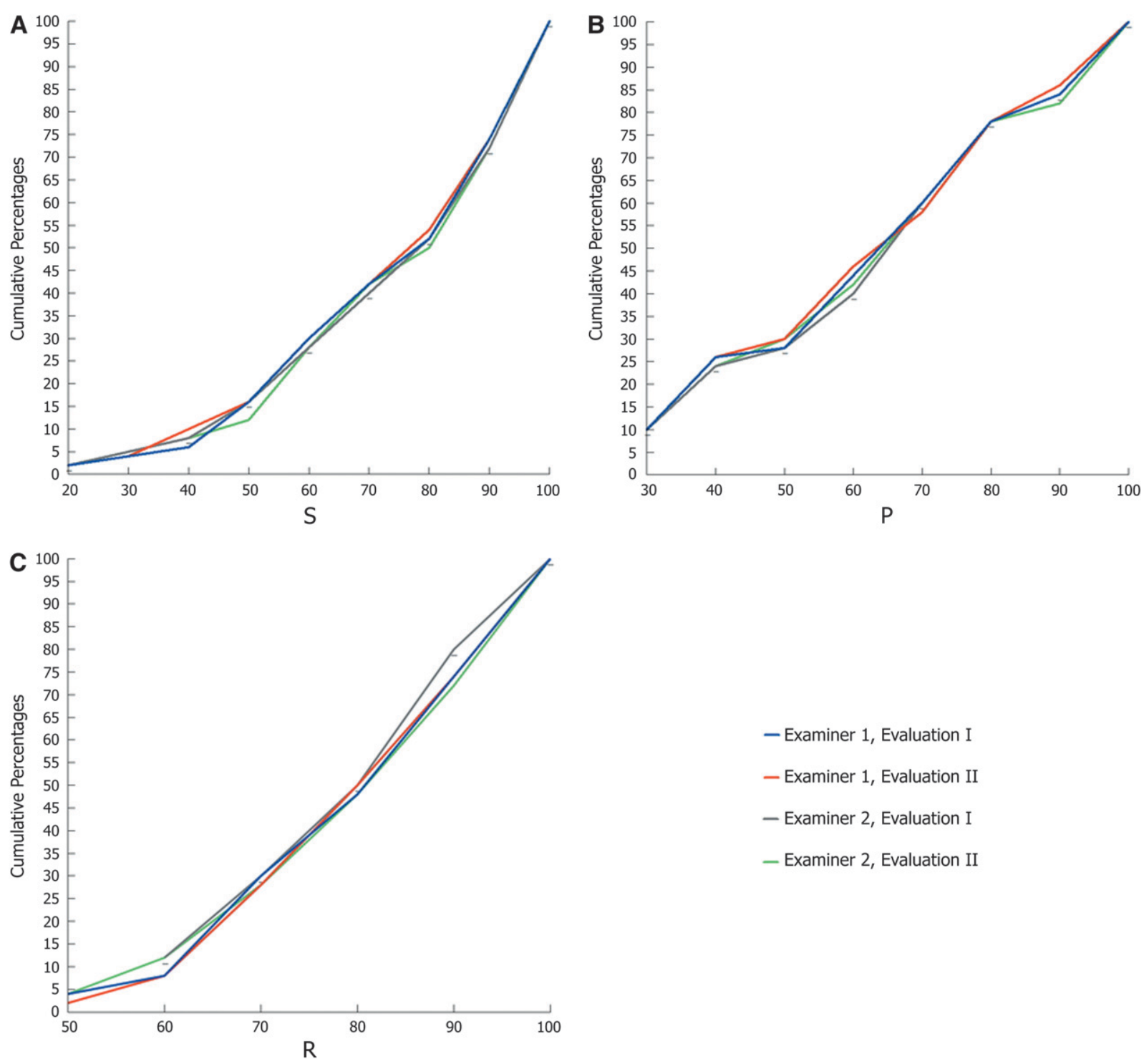

Figure 2.

Distribution of cumulative percentages depending on $\mathbf{S}(\mathbf{A}), P(\mathbf{B})$, and $R(\mathbf{C})$ grade, evaluation period, and examiner.

than the thick tissue biotype. Similarly, implants with a buccal shoulder position had three times more recession than implants with a lingual/palatal shoulder position. Using the CEI, which includes both soft and hard tissue assessments, the results from the present study show that CEI can be a good index to adequately predict future implant esthetics. As previously stated, the CEI analyzes soft tissue, hard tissue, and restoration because all of these influence the esthetic outcomes of implants. Different variations of these three parameters were evaluated and graded as adequate (rating $20 \%$ ), compromised (rating 10\%), and deficient (rating $0 \%$ ). A simple rating by three grades, adequate, compromised, and deficient, was chosen because if more detailed ratings were applied then the results would become difficult to interpret, especially in the in- termediate category. This concern was reported by Trisi and $\mathrm{Rao}^{13}$ in bone scoring and by Furhauser et al. ${ }^{5}$ in soft tissue assessment.

An analysis of CEI for 50 anterior maxillary implant-supported restorations showed good intraand interobserver agreement for the S and R. Only interobserver agreement for the overall $\mathrm{R}$ was rated as moderate $(0.54$ and 0.52$)$. This can be attributed to the lack of prosthetic restorative experience of the examiners. Both examiners were specialized in oral surgery. This was further supported by the study published by Meijer et al. ${ }^{10}$ in which the prosthodontists had better intraobserver implant-crown esthetic-index agreement than the oral-maxillofacial surgeons. The appreciation of the esthetic outcome of the single implant-supported crowns was rated 
Table 3.

S, P, and R Evaluation Grades (\%) Assessed by Examiners 1 and 2 in Evaluations I and II

\begin{tabular}{|c|c|c|c|c|c|c|c|c|c|c|c|c|}
\hline \multirow[b]{2}{*}{$\begin{array}{l}\text { Parameter } \\
\text { Evaluation } \\
\text { Grade }\end{array}$} & \multicolumn{3}{|c|}{$\begin{array}{l}\text { Examiner I/ } \\
\text { Evaluation I }\end{array}$} & \multicolumn{3}{|c|}{$\begin{array}{l}\text { Examiner I/ } \\
\text { Evaluation II }\end{array}$} & \multicolumn{3}{|c|}{$\begin{array}{l}\text { Examiner } 2 / \\
\text { Evaluation I }\end{array}$} & \multicolumn{3}{|c|}{$\begin{array}{l}\text { Examiner } 2 / \\
\text { Evaluation II }\end{array}$} \\
\hline & $n$ & $\begin{array}{c}\text { Index } \\
\text { Within } \\
\text { Evaluation } \\
\text { Grades }\end{array}$ & $\begin{array}{c}\text { Cumulative } \\
\text { Index } \\
\text { Grade }\end{array}$ & $n$ & $\begin{array}{c}\text { Index } \\
\text { Within } \\
\text { Evaluation } \\
\text { Grades }\end{array}$ & $\begin{array}{c}\text { Cumulative } \\
\text { Index } \\
\text { Grade }\end{array}$ & $n$ & $\begin{array}{c}\text { Index } \\
\text { Within } \\
\text { Evaluation } \\
\text { Grades }\end{array}$ & $\begin{array}{c}\text { Cumulative } \\
\text { Index } \\
\text { Grade }\end{array}$ & $n$ & $\begin{array}{c}\text { Index } \\
\text { Within } \\
\text { Evaluation } \\
\text { Grades }\end{array}$ & $\begin{array}{c}\text { Cumulative } \\
\text { Index } \\
\text { Grade }\end{array}$ \\
\hline \multicolumn{13}{|l|}{ S } \\
\hline \multicolumn{13}{|l|}{ Deficient } \\
\hline 20 & 1 & 2 & 2 & I & 2 & 2 & I & 2 & 2 & I & 2 & 2 \\
\hline 30 & 1 & 2 & 4 & I & 2 & 4 & 0 & 0 & 0 & 0 & 0 & 0 \\
\hline 40 & I & 2 & 6 & 0 & 0 & 0 & 3 & 6 & 8 & 3 & 6 & 8 \\
\hline 50 & 5 & 10 & 16 & 6 & 12 & 16 & 4 & 8 & 16 & 2 & 4 & 12 \\
\hline \multicolumn{13}{|c|}{ Compromised } \\
\hline 60 & 7 & 14 & 30 & 7 & 14 & 30 & 6 & 12 & 28 & 8 & 16 & 28 \\
\hline 70 & 6 & 12 & 42 & 6 & 12 & 42 & 6 & 12 & 40 & 7 & 14 & 42 \\
\hline 80 & 5 & 10 & 52 & 6 & 12 & 54 & 6 & 12 & 52 & 4 & 8 & 50 \\
\hline 90 & 11 & 22 & 74 & 10 & 20 & 74 & 10 & 20 & 72 & 11 & 22 & 72 \\
\hline \multicolumn{13}{|c|}{ Adequate } \\
\hline 100 & 13 & 26 & 100 & 13 & 26 & 100 & 14 & 28 & 100 & 14 & 28 & 100 \\
\hline Mean (SD) & \multicolumn{3}{|c|}{$77.4(20.98)$} & \multicolumn{3}{|c|}{$77.4(20.58)$} & \multicolumn{3}{|c|}{$78.0(20.9)$} & \multicolumn{3}{|c|}{$78.4(20.54)$} \\
\hline \multicolumn{13}{|l|}{ P } \\
\hline \multicolumn{13}{|l|}{ Deficient } \\
\hline 30 & 30 & 30 & 30 & 30 & 30 & 30 & 30 & 30 & 30 & 30 & 30 & 30 \\
\hline 40 & 40 & 40 & 40 & 40 & 40 & 40 & 40 & 40 & 40 & 40 & 40 & 40 \\
\hline 50 & 50 & 50 & 50 & 50 & 50 & 50 & 50 & 50 & 50 & 50 & 50 & 50 \\
\hline \multicolumn{13}{|c|}{ Compromised } \\
\hline 60 & 8 & 16 & 44 & 8 & 16 & 46 & 6 & 12 & 40 & 6 & 12 & 42 \\
\hline 70 & 8 & 16 & 60 & 6 & 12 & 58 & 10 & 20 & 60 & 9 & 18 & 60 \\
\hline 80 & 9 & 18 & 78 & 10 & 20 & 78 & 9 & 18 & 78 & 9 & 18 & 78 \\
\hline 90 & 3 & 6 & 84 & 4 & 8 & 86 & 3 & 6 & 84 & 2 & 4 & 82 \\
\hline $\begin{array}{l}\text { Adequat } \\
100\end{array}$ & 8 & 16 & 100 & 7 & 14 & 100 & 8 & 16 & 100 & 9 & 18 & 100 \\
\hline Mean (SD) & \multicolumn{3}{|c|}{$67.4(22.7)$} & \multicolumn{3}{|c|}{$66.6(22.64)$} & \multicolumn{3}{|c|}{$67.6(22.46)$} & \multicolumn{3}{|c|}{$67.4(22.84)$} \\
\hline \multicolumn{13}{|l|}{ R } \\
\hline \multicolumn{13}{|c|}{ Deficient } \\
\hline 50 & 2 & 4 & 4 & I & 2 & 2 & 0 & 0 & 0 & 2 & 4 & 4 \\
\hline \multicolumn{13}{|c|}{ Compromised } \\
\hline 70 & 11 & 22 & 30 & 10 & 20 & 28 & 9 & 18 & 30 & 8 & 16 & 28 \\
\hline 80 & 9 & 18 & 48 & 11 & 22 & 50 & 10 & 20 & 50 & 10 & 20 & 48 \\
\hline 90 & 13 & 26 & 74 & 12 & 24 & 74 & 15 & 30 & 80 & 12 & 24 & 72 \\
\hline \multicolumn{13}{|c|}{ Adequate } \\
\hline $\begin{array}{c}100 \\
\text { Mean (SD) }\end{array}$ & 13 & $\begin{array}{l}26 \\
83.6(1\end{array}$ & $3.96)^{100}$ & 13 & $\begin{array}{l}26 \\
83.8\end{array}$ & $3.38)^{100}$ & 10 & $\begin{array}{l}20 \\
82.8(1\end{array}$ & $3.1)^{100}$ & 14 & $\begin{array}{l}28 \\
83.6(1\end{array}$ & ${ }_{4.54)^{100}}^{100}$ \\
\hline
\end{tabular}

higher by patients than by prosthodontists. ${ }^{14}$ It is evident that dental professionals are less satisfied with respect to the result than their patients. ${ }^{14-16}$ Meijndert et al. $^{16}$ reported that the peri-implant mucosa was rated as less satisfactory than the implant-supported crown by dental professionals and patients.
Single-parameter analyses showed that the lowest (moderate) intra- and interobserver agreement was for the subjective parameters of $\mathrm{S}$ (soft tissue color and texture variations) and $\mathrm{R}$ (crown surface roughness and ridges and color and translucency). Subjective parameters were reduced to a minimum for $S$ 
A

\section{S100, P100, R100}

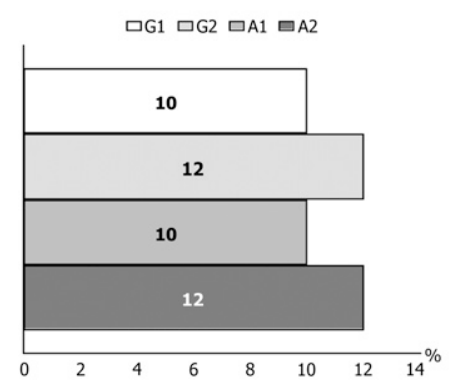

B

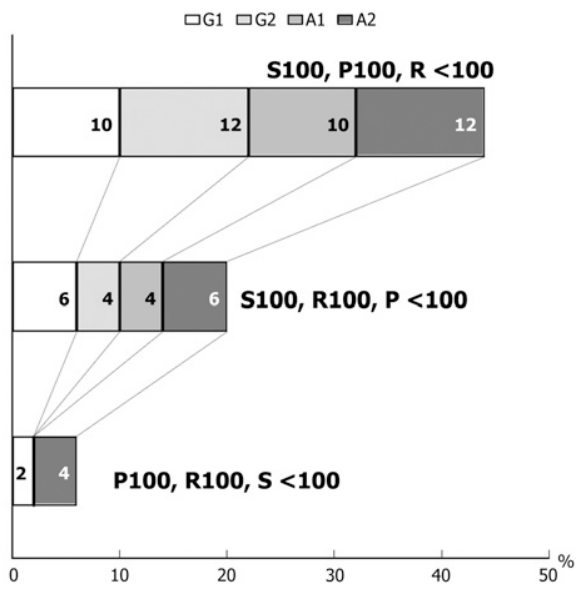

Figure 3.

A) Adequate (SI00, PI00, and RI00) CEI distribution evaluated by surgeons I and 2 in both evaluation periods. B) CEI distribution when one of the indexes was $<100$ as evaluated by surgeons $\mid$ and 2 in both evaluation periods. $G \mid$ = examiner I, evaluation I; $G 2$ = examiner I, evaluation II; $\mathrm{A}$ I = examiner 2, evaluation I; A2 = examiner 2, evaluation II.

thors report no conflicts of interest related to this study.

\section{REFERENCES}

1. Kazor CE, Al-Shammari K, Sarmment DP, Misch CE, Wang HL. Implant plastic surgery: A review and rationale. J Oral Implantol 2004;30:240-254.

2. Phillips K, Kois JC. Aesthetic periimplant site development. The restorative connection. Dent Clin North Am 1998;42:57-70.

3. Belser U, Buser D, Higginbottom F. Consensus statements and recommended clinical procedures regarding esthetics in implant dentistry. Int $J$ Oral Maxillofac Implants 2004; 19(Suppl.):73-74.

4. Juodzbalys G, Wang HL. Soft and hard tissue assessment of immediate implant placement: A case series. Clin Oral Implants Res 2007;18: 237-243.

5. Furhauser R, Florescu D, Benesch T, Haas R, Mailath G, Watzek G. Evalu-

evaluation. This is in agreement with Belser et al., ${ }^{11}$ who developed the PES that combines both soft tissue color and texture into one score in an attempt to minimize the subjectivity of the index evaluation. Nonetheless, registered differences among ratings of single parameters have no significant influence on the overall S, P, and R CEI grade (Table 3). In addition, CEI is a reliable esthetic index for grading implant esthetic outcomes. This is supported by the fact that both examiners independently scored an adequate CEI of S100, P100, and R100 in 10\% and $12 \%$ of cases for evaluations I and II, respectively (Fig. 3A).

The analysis of the importance of each component of the CEI showed that, in situations where the CEI was $\mathrm{S} 100, \mathrm{P} 100$, and $\mathrm{R}<100 \%$, the number of cases was the same as those reported with an adequate CEI (Fig. 3B). This suggests that implant-supported restoration quality can be compromised or deficient even if the $\mathrm{S}$ and $\mathrm{P}$ are adequate.

\section{CONCLUSIONS}

The CEI presented in this article consists of an assessment of adjacent soft and hard tissues and implant restorations and was found to be a reproducible tool for scoring the predictability of anterior implant esthetics. However, prospective clinical trials involving examiners with a prosthetic background are needed to further validate the long-term stability of this index.

\section{ACIKNOWLEDGMENTS}

The authors thank Drs. Jill Bashutski and JiaHui Fu, Department of Periodontics and Oral Medicine, University of Michigan, Ann Arbor, Michigan, for their help in editing the manuscript of this article. The au- ation of soft tissue around single-tooth implant crowns: The pink esthetic score. Clin Oral Implants Res 2005; 16:639-644.

6. Chen ST, Darby IB, Reynolds EC. A prospective clinical study of non-submerged immediate implants: Clinical outcomes and esthetic results. Clin Oral Implants Res 2007;18:552-562.

7. Evans CDJ, Chen ST. Esthetic outcomes of immediate implant placements. Clin Oral Implants Res 2008; 19:73-80.

8. Juodzbalys G, Sakavicius D, Wang H-L. Classification of extraction sockets based upon soft and hard tissue components. J Periodontol 2008;79:413-424.

9. De Rouck T, Collys K, Cosyn J. Single-tooth replacement in the anterior maxilla by means of immediate implantation and provisionalization: A review. Int $J$ Oral Maxillofac Implants 2008;23:897-904.

10. Meijer HJ, Stellingsma K, Meijndert L, Raghoebar GM. A new index for rating aesthetics of implant-supported single crowns and adjacent soft tissues - The Implant Crown Aesthetic Index. Clin Oral Implants Res 2005; 16:645-649.

11. Belser UC, Grütter L, Vailati F, Bornstein MM, Weber HP, Buser D. Outcome evaluation of early placed maxillary anterior single-tooth implants using objective esthetic criteria: A cross-sectional, retrospective study in 45 patients with a 2 - to 4 -year follow-up using pink and white esthetic scores. J Periodontol 2009; 80:140-151.

12. Bianchi AE, Sanfilippo F. Single-tooth replacement by immediate implant and connective tissue graft: A 1-9-year clinical evaluation. Clin Oral Implants Res 2004;15:269-277.

13. Trisi P, Rao W. Bone classification: Clinical-histomorphometric comparison. Clin Oral Implants Res 1999;10:1-7.

14. Chang M, Odman PA, Wennström JL, Andersson B. Esthetic outcome of implant-supported singletooth replacements assessed by the patient and by prosthodontists. Int J Prosthodont 1999;12:335341 . 
15. De Rouck T, Collys K, Cosyn J. Immediate singletooth implants in the anterior maxilla: A 1-year case cohort study on hard and soft tissue response. J Clin Periodontol 2008;35:649-657.

16. Meijndert L, Meijer HJ, Stellingsma K, Stegenga B, Raghoebar GM. Evaluation of aesthetics of implantsupported single-tooth replacements using different bone augmentation procedures: A prospective ran- domized clinical study. Clin Oral Implants Res 2007; 18:715-719.

Correspondence: Prof. Gintaras Juodzbalys, Vainiku 12, LT46383 Kaunas, Lithuania. E-mail: gintaras@stilusoptimus.lt.

Submitted July 6, 2009; accepted for publication August 30, 2009 